\title{
Informality and labour market segmentation: the case of Argentina
}

\author{
Luis Beccaria and Fernando Groisman
}

ABSTRACT

The document evaluates the presence of segmentation in the Argentinean labour market. The analysis is centred on the comparison of the earnings of formal and informal workers. Two different approaches to the definition of informality are used. The existence of a formal premium is tested using dynamic data and semiparametric techniques. The period analysed is 1996-2006 for all urban surveyed areas. Our results support the segmentation hypothesis for the Argentine urban labour market: workers with similar probabilities of entering/exiting across sectors obtain different earnings. labeccari@gmail.com

Fernando Groisman is a researcher at the Council of Scientific and Technical Research (CONICET) and at the University of Buenos Aires (UBs) in Argentina. groismanf@hotmail.com 


\section{I}

\section{Introduction}

The persistence of high levels of informality in Latin America, even during periods of economic growth, has led to numerous investigations on this subject. Much of this research has focused on testing the hypothesis of a dual or segmented labour market, ${ }^{1}$ largely by means of empirical evaluation of earning gaps between formality and informality. Most of these studies have found a positive premium to formality, a result that usually leads to heated discussions about its implications. Specifically, a line of argument links those results to the existence of segmentation; there are, however, differences regarding the causes of such phenomena. ${ }^{2}$

From one point of view, earnings gaps are one of the consequences of limitations on competition - labour regulations and/or trade unions- - Another view, however, holds that in conditions of weak labour demand, some workers have no access to jobs in the formal sector and are forced to accept informal jobs with lower earnings. In these conditions, gaps persist even when unemployment exceeds the frictional level. It is also pointed out that, for several reasons, workers may prefer to evade the costs of protection by entering the informal sector. Under this assumption, however, the earning gap would be in favour of informal workers. ${ }^{3}$ Another quite common argument is that the lower earnings of informal workers reflect the value of non-pecuniary benefits of these jobs, ${ }^{4}$ with independent workers preferring autonomous work, secondary workers - women and youth - choosing informal wage jobs because of time flexibility, and older workers and low-skilled youth being compensated with on-the-job training.

Empirical procedures are also questioned. According to the segmentation hypothesis, differences in the market

\footnotetext{
1 Since Lewis (1954), other relevant papers about the nature of dualistic labour markets are Harris and Todaro (1970), Fields (1975) and (1990), and Pradhan and Van Soest (1995).

${ }^{2}$ See Heckman and Sedlacek (1985), Dickens and Lang (1988), Evans and Leighton (1989), Pagés-Serra and Stampini (2007), Maloney (1999), and Pratap and Quintín (2006).

${ }^{3}$ The negative formal premium measured would indicate that earnings from informal jobs compensate for the loss of social protection and the lower stability.

${ }^{4}$ See Killingsworth (1987), Magnac (1991), Maloney (1999) and
} Perry and others (2007). for informal workers and for all other workers may lead to earnings equations of a different functional form for the two groups. There is some evidence to back this idea. Earning functions that incorporate a variable for the formal/informal sector and tests estimating differences in earning functions from diverse sectors usually yield more parsimonious models of the distribution of the labour earnings than those considering only human capital or single labour market variables. However, it has been argued (see, for example, Heckman and Hotz, 1986) that this may simply reflect the bias induced by the selective composition of the samples of workers. Under this premise, the better performance showed by segmentation models would be mainly due to the parametric nature of the earnings equations utilized. In other words, ordinary least squares (OLS) estimates would be biased by selectivity, because individuals choose the sector in which to work according to the wages on offer and/or productive characteristics that are generally different across sectors.

Other methodologies appear to be more suitable for avoiding the limitations of these techniques. Some alternative approaches employ semiparametric methods or selection bias correction techniques. But even premiums estimated using such procedures may arise from the effect of non-observed (and/or non-observable) variables - formal firms may hire more skilled or more intelligent workers for example - and dynamic data are therefore required in order to take into account non-observable variables. Specifically, this paper evaluates the existence of a formal premium using dynamic data and semiparametric models. We compare changes in earnings experienced by workers who move from formality to informality (and from informality to formality) vis-à-vis those remaining in the formal (informal) sector. To overcome restrictions arising from the selective composition of the samples, the comparisons are made between workers with similar probabilities of sectoral transition based on observable characteristics.

Two different approaches to the definition of informality are employed: the traditional definition employed by the International Labour Organization (ILO) based on numbers of workers (informal sector employment) and the new one considering compliance 
with legal and regulating aspects (informal employment). Furthermore, in order to deepen the analysis on earning gaps, each sector is sometimes disaggregated by some of its components.

Our results support the segmentation hypothesis for the Argentine urban labour market: workers with observably similar probabilities of entering/exiting across sectors obtain different earnings.
After this Introduction, this article is structured as follows: section II identifies informality, or the informal sector of the economy, whose extent and recent evolution is discussed in section III. Section IV examines earnings differences between the formal and informal sectors. Section V estimated the formality premium using a semiparametric panel data model. Lastly, section VI concludes.

\section{II}

\section{Identifying informality}

Informality —or informal sector or informal economy-is a category used to improve the description and analysis of the functioning of the economy and, in particular, of the labour markets of developing countries. The original description by ILO $(1972)^{5}$ and later developments, mainly in Latin America, linked the existence of informal units of production in less developed countries to the incapacity of their economies to create sufficient jobs for the labour force. While in developed countries this situation would lead to unemployment, in developing countries it causes the emergence and persistence of a large proportion of employment concentrated in small, low-productivity units. This sometimes consists simply of self-employment and, in other cases, of wage-earners working in small establishments. These production units are able to subsist by exploiting some market "interstices" and/or because of the low remuneration paid and received. In this traditional ILO view, informal units typically operate in easy-entry activities and show an unclear separation between capital and labour.

However, the idea of informality is also associated with other characteristics and explanations for its extent, even in developed countries. For example, informality is identified with non-compliance with labour and other regulations (mainly tax evasion) by certain firms. Portes, Castells and Benton (1989) view the growing significance of informality as an outcome of cost-cutting strategies in a highly competitive environment associated with the

\footnotetext{
5 The term "informality" appears to have been introduced, however,
} in Hart (1973). new international division of labour emerging in the late 1980s. In this case, hidden informality may exist even in large firms if they hire workers not registered with the social security system. Other authors - notably, De Soto (1987) — see the non-registration of many small units in underdeveloped countries as a response to cumbersome regulations that are better suited to large firms. There is clearly much overlap between units classified according to this and to the traditional ILO perspective.

Both perspectives are taken into account to some extent in the recent recommendations by the International Conference of Labour Statisticians regarding the definition of informality. These distinguish informal sector employment (in general terms, defined according to the traditional ILo perspective) from informal employment, i.e. those not covered by labour legislation. ${ }^{6}$ In this paper, we adopt both views in order to differentiate between formality and informality.

Following a long tradition in Latin America, firm size will be considered as the criterion to distinguish between formal and informal establishments. Workers in the formal sector are defined as those in firms having six employees or more. ${ }^{7}$ Public sector units are also included here - not only public administration but all the agencies at the national, provincial or municipal

\footnotetext{
${ }^{6}$ See Hussmanns (2005).

7 Firm size is the usual proxy for productivity when data from household surveys are used. However, a few small firms may be found with high levels of productivity (especially in the information technology (IT) sector), which may result in underestimation of the wage gap between formal and informal sectors. Nevertheless, the great majority of microenterprises show low productivity.
} 
levels. In addition, self-employed workers who have completed higher education were treated as part of the formal sector, so as to set a distinction with respect to professionals. ${ }^{8}$

Informal workers are accordingly non-registered wage earners and the non-professional self-employed. A wage earner will be considered informal if he or she is not registered in the social security system. This group will also include workers in domestic service and the beneficiaries of employment schemes.

${ }^{8}$ Consisting mainly of self-employed lawyers, physicians, accountants, and similar professions.
The following table summarizes the definitions used:

\begin{tabular}{lcc}
\hline Sector of origin & $\begin{array}{c}\text { Informal } \\
\text { employment }\end{array}$ & $\begin{array}{c}\text { Informal } \\
\text { sector } \\
\text { employment }\end{array}$ \\
\hline $\begin{array}{l}\text { Formal non-wage earners } \\
\text { Informal non-wage earners }\end{array}$ & $\mathrm{x}$ & $\mathrm{x}$ \\
$\begin{array}{l}\text { Formal registered wage earners } \\
\text { Formal non-registered wage earners }\end{array}$ & $\mathrm{x}$ & $\mathrm{x}$ \\
Informal registered wage earners & $\mathrm{x}$ & $\mathrm{x}$ \\
Informal non-registered wage earners & $\mathrm{x}$ & $\mathrm{x}$ \\
$\begin{array}{l}\text { Domestic service workers } \\
\text { Family workers }\end{array}$ & $\mathrm{x}$ & \\
Employment schemes & $\mathrm{x}$ & \\
\hline
\end{tabular}

Source: Prepared by the authors.

\section{III}

\section{Extent and recent evolution of informality}

The existence of income differences along the formalinformal spectrum is a relevant issue in Argentina given the importance of informality in the economic and employment structure and its persistence over time. This short section examines some evidence of the importance of this sector.

Informal employment -as defined aboveaccounted for some 55\% of Argentine urban employment in 2005. Non-registered wage earners made up $24 \%$ of that figure, the informal self-employed $18 \%$ and domestic servants accounted for almost $8 \%$; the rest were enrolled in employment schemes. On the other hand, $38 \%$ of workers were in informal sector employment, $20 \%$ of whom were working for small firms (see table 1).

Despite the difficulties that the Argentine labour market faced during 1990s and 2000s, when unemployment increased from $9 \%$ in 1993 to $16 \%$ in 2003, the relative size of informal sector employment did not change. This indicates that the structural reforms that took place during these years had an impact on the informal sector, and that many activities in that sector were not typical "informal" activities (Sánchez, Palmieri and Ferrero 1976). However, there was a significant increase in the number of non-registered wage earners, which explains the spread - although modest in relation to labour difficulties - of informal employment. Between 1990 and 2010, the main feature of labour market structures was the increase in the number of non-registered wage earners (excluding those in domestic service and employment schemes). In 1993, such workers accounted for $29 \%$ of the total waged labour force, in 2003, that figure had risen to $41 \%$ (excluding employment scheme and domestic service workers).

During the period of economic growth that started at the end of 2002, both informal sector employment and informal employment accounted for less of the total employment rate, mainly as a result of a fall in the number of self-employed workers. The number of non-registered wage earners remained stable (although this group did shrink as a proportion of all wage earners because of the increase in registered occupations). 


\begin{tabular}{|c|c|c|c|c|c|c|c|c|}
\hline & & $\begin{array}{c}\text { Oct } \\
1993\end{array}$ & $\begin{array}{c}\text { Oct } \\
1998\end{array}$ & $\begin{array}{c}\text { Oct } \\
2001\end{array}$ & $\begin{array}{l}\text { May } \\
2003\end{array}$ & $\begin{array}{l}\text { 2nd quarter } \\
2003\end{array}$ & $\begin{array}{l}\text { 2nd quarter } \\
2003\end{array}$ & $\begin{array}{l}\text { 2nd quarter } \\
2005\end{array}$ \\
\hline 1 & Formal non-wage earners & 4.5 & 4.5 & 4.3 & 4.4 & 4.2 & 4.7 & 5.4 \\
\hline 2 & Informal non-wage earners & 23.4 & 19.4 & 21.2 & 20.7 & 20.8 & 19.6 & 18.4 \\
\hline 3 & Formal registered wage earners & 38.7 & 39.1 & 37.9 & 34.2 & 30.1 & 30.9 & 34.1 \\
\hline 4 & Formal non-registered wage earners & 8.3 & 11.2 & 9.4 & 9.7 & 7.7 & 8.7 & 9.5 \\
\hline 5 & Informal registered wage earners & 5.7 & 5.5 & 5.2 & 5.0 & 6.3 & 5.8 & 5.9 \\
\hline 6 & Informal non-registered wage earners & 10.3 & 11.8 & 12.1 & 11.2 & 14.5 & 14.4 & 14.0 \\
\hline 7 & Domestic service & 7.9 & 7.3 & 7.6 & 6.8 & 7.8 & 7.5 & 7.7 \\
\hline 8 & Family workers & 1.3 & 1.3 & 0.8 & 1.0 & 1.6 & 1.7 & 1.2 \\
\hline \multirow[t]{3}{*}{9} & Employment schemes & 0.0 & 0.0 & 1.4 & 7.0 & 7.0 & 6.7 & 3.7 \\
\hline & Total & 100 & 100 & 100 & 100 & 100 & 100 & 100 \\
\hline & With employment schemes & & & & & & & \\
\hline$(2+4+6+7+8+9)$ & Informal employment & 51.1 & 50.9 & 52.5 & 56.4 & 59.4 & 58.6 & 54.6 \\
\hline \multirow{4}{*}{$(2+5+6)$} & Informal sector employment & 39.4 & 36.7 & 38.6 & 36.9 & 41.6 & 39.7 & 38.4 \\
\hline & $\begin{array}{l}\text { Non-registered wage earners }+ \\
\text { employment schemes }\end{array}$ & 18.6 & 23.0 & 22.9 & 27.9 & 29.2 & 29.9 & 27.2 \\
\hline & Non-registered wage earners & 18.6 & 23.0 & 21.5 & 20.9 & 22.1 & 23.1 & 23.6 \\
\hline & Without employment schemes & & & & & & & \\
\hline$(2+4+6+7+8)$ & Informal employment & 51.1 & 50.9 & 51.8 & 53.1 & 56.3 & 55.6 & 52.8 \\
\hline \multirow[t]{3}{*}{$(2+5+6)$} & Informal sector employment & 39.4 & 36.7 & 39.1 & 39.7 & 44.7 & 42.6 & 39.8 \\
\hline & $\begin{array}{l}\text { Non-registered wage earners }+ \\
\text { domestic service }\end{array}$ & 26.5 & 30.2 & 29.5 & 29.8 & 32.2 & 32.8 & 32.4 \\
\hline & Non-registered wage earners & 18.6 & 23.0 & 21.8 & 22.5 & 23.8 & 24.8 & 24.5 \\
\hline
\end{tabular}

Source: Prepared by the authors, on the basis of data from permanent household surveys.

\section{IV}

\section{Formal-informal earnings differences: some facts and previous results}

The difference between the mean earnings of groups of workers and other disaggregated groups can be calculated from table 2. On average, the hourly earnings of those working in the informal sector are $47 \%$ less than of those in the formal sector. The differences between informal and formal employment and between non-registered and registered wage earners are $48 \%$ and $42 \%$ respectively. The gaps widen when monthly incomes are considered, as informality is linked to underemployment (see table 2).

Some studies isolate the effects of informality from those caused by other variable income determinants by estimating earning functions using cross-section data. For example, Beccaria and Groisman (2008) calculate hourly earnings gaps of about $40 \%$ between wage workers, based on data from 2005, while the gap between formal sector employment and informal sector employment was lower. According to Perry and others (2007) the gap between registered and non-registered workers is about $35 \%$, while Pratap and Quintín (2006) calculate that the gap between registered and non-registered wage earners is between $22 \%$ and $28 \%$, depending on the model, based on information for Greater Buenos Aires only for the period 1993-1995. These figures are similar to those estimated by Beccaria and Groisman (2008) for 1993.

This approach, based on earnings functions, relies on parametric assumptions. The basic methodological problem, which is not restricted to this issue, is that segmented or dualistic models may fit better because earnings functions are non-linear. If the underlying earnings function is sufficiently non-linear, the segmentation 
Argentina: earnings and hours worked, second quarter, 2005

(All urban areas surveyed, in percentages)

\begin{tabular}{|c|c|c|c|c|c|c|}
\hline & $\begin{array}{c}\text { Hours } \\
\text { per week }\end{array}$ & $\begin{array}{c}\text { Monthly } \\
\text { earnings } \\
\text { (Argentine } \\
\text { pesos) }\end{array}$ & $\begin{array}{l}\text { Hourly } \\
\text { earnings } \\
\text { (Argentine } \\
\text { pesos) }\end{array}$ & $\begin{array}{c}\text { Hours } \\
\text { per week }\end{array}$ & $\begin{array}{c}\text { Monthly } \\
\text { earnings } \\
\text { (Argentine } \\
\text { pesos) }\end{array}$ & $\begin{array}{c}\text { Hourly } \\
\text { earnings } \\
\text { (Argentine } \\
\text { pesos) }\end{array}$ \\
\hline & \multicolumn{3}{|c|}{ Informal sector employment } & \multicolumn{3}{|c|}{ Formal sector employment } \\
\hline Registered wage earners & 42.0 & 486.8 & 3.3 & 47.7 & 776.2 & 4.1 \\
\hline Medium education level & 42.5 & 711.8 & 4.5 & 43.1 & 1047.8 & 6.2 \\
\hline High education level & 38.8 & 936.1 & 6.1 & 37.8 & 1566.9 & 11.3 \\
\hline \multirow[t]{2}{*}{ Average } & 42.1 & 582.1 & 3.8 & 42.9 & 1128.2 & 7.2 \\
\hline & \multicolumn{3}{|c|}{ Informal employment } & \multicolumn{3}{|c|}{ Formal employment } \\
\hline Low education level & 38.1 & 417.8 & 3.2 & 48.4 & 897.1 & 4.7 \\
\hline Medium education level & 39.3 & 626.6 & 4.4 & 44.7 & 1112.4 & 6.3 \\
\hline High education level & 36.1 & 1092.2 & 10.3 & 38.1 & 1567.4 & 10.9 \\
\hline \multirow[t]{2}{*}{ Average } & 38.4 & 510.6 & 3.8 & 43.5 & 1205.6 & 7.4 \\
\hline & \multicolumn{3}{|c|}{ Non-registered wage earners } & \multicolumn{3}{|c|}{ Registered wage earners } \\
\hline Low education level & 43.1 & 432.1 & 2.6 & 48.3 & 881.9 & 4.6 \\
\hline Medium education level & 38.0 & 531.3 & 3.8 & 44.5 & 1070.7 & 6.1 \\
\hline High education level & 36.7 & 1155.1 & 10.9 & 36.8 & 1435.8 & 9.6 \\
\hline Average & 40.8 & 530.8 & 3.8 & 43.7 & 1104.8 & 6.5 \\
\hline
\end{tabular}

Source: Prepared by the authors, on the basis of data from permanent household surveys.

tests will be more parsimonious. Moreover, it has been suggested that the Heckman correction does not control for selection bias.

Hence, semiparametric methods are used in various studies concerning different countries. ${ }^{9}$ Beccaria and Groisman (2008) apply such an approach, based on quantile regression and propensity score methods, in the case of Argentina. The formality premium results are similar to those reported in the aforementioned 2008 paper, which used income functions. Pratap and Quintín (2006) also use propensity score matching, an alternative approach that relaxes the parametric assumptions of the earnings functions. In this case, the results show that the formal premium disappears, contradicting those studies that used income functions. The earnings gap between registered and non-registered employees only re-emerges when we compare the wages of employees of firms of different sizes (i.e. when size is excluded from the variables used to estimate the propensity scores).

The effect of unobserved variables is not properly controlled for when cross-section data are used. One popular approach to remedy this is to use fixed effects models. Pratap and Quintín (2006) observe a standard

\footnotetext{
${ }^{9}$ For example, Maloney (1999) in the case of Mexico, Packard (2007) in the case of Chile, and Perry and others (2007) when examining various Latin American countries.
}

fixed-effect regression on $\log$ real hourly wages that yields a positive and significant formal sector premium.

Another alternative is to use semiparametric panel data models. By applying propensity score matching to panel data we can calculate whether the variation in earnings of formal workers in a particular sector is similar to that of formal workers who moved to an informal occupation. No difference would indicate that the labour market is not segmented along formal-informal lines. Pratap and Quintín (2006) use this approach, but conclude that the results were inconclusive, owing, among other things, to the small sample size (they use data limited to Greater Buenos Aires for the period 1993-1995).

Perry and others (2007) examine estimates of formalinformal earnings gaps, produced by Arias and Khamis using a propensity score approach applied to panel data, which reveal a significant positive difference between the incomes of registered and non-registered wage earners. However, these differences become insignificant, or even negative, when the earnings of wage earners and non-wage earners are compared.

In the following section, we seek to build on the work of Pratap and Quintín (2006), by using a broader panel data set (covering all urban surveyed areas and longer periods, specifically 1996-2003 and 2004-2006), and taking into account the two definitions of informality set out in section II. 


\section{Estimating the formality premium using a semiparametric panel data model}

\section{Method}

This paper adopts a semiparametric approach to determine whether there is a difference between earnings in the formal and informal sectors. The propensity score method is used to compare the earnings of formal and informal workers with similar characteristics to identify the presence of any differences. To identify those workers that are "most similar," a score is attributed to each observation. This score is based on the likelihood that a person works in the formal sector according to probability models (such as probit), taking into account the relevant variables available in the data set. Thus, an average of the differences between persons with similar scores $-\alpha-$ is calculated using the following formulation:

$$
\alpha^{M}=\frac{1}{N_{F}} \sum_{i \in I}\left(w_{i}^{F}-\sum_{j \in I} \eta_{i j} w_{j}^{I}\right)
$$

where $F$ is the formal sector, $I$ is the informal sector, $N_{F}$ is the number of formal workers and $\eta_{i j}$ is the weight of informal worker $j$ within the comparison group of formal worker $i$.

The weight of each observation can be determined by different matching algorithms. One that is frequently used is the nearest-neighbour method, where $\eta_{i j}=1$ for $\min \left|p_{i}-p_{j}\right|$ and zero for others, and $p_{k}$ is the propensity score of worker $k$. An alternative algorithm is radius matching, which establishes a maximum propensity score radius and the average earnings of all workers within that radius are considered. Kernel matching is another variant, whereby the earnings of formal workers (i) are compared to the weighted average earnings of informal workers $(j)$, with the weight inversely related to the distance between the scores of $i$ and $j$, i.e. $\left|p_{i}-p_{j}\right|$.

This semiparametric method requires no assumption on the form of earning functions and limits comparisons to observably similar workers.

While this method, as it is usually considered, addresses the selection bias problem, it fails to solve another difficulty (that is also common to parametric methods), namely the effect of unobserved variables. Segmentation studies are often criticized for failing to take into account the effect of generally unobserved variables that affect earnings. Therefore, in line with other recent studies, we have adopted the propensity score approach, not to compare the earnings of formal and informal workers at a certain point in time, but rather to evaluate differences in earnings over time. Using panel data, we contrast the difference in the earnings of workers who move from formality to informality from period 0 to period $t$ with that of workers who remain in the formal sector in both periods. Similarly, the earnings differences of informal workers who take up a formal job are compared to those of workers who remain in the informal sector. The average difference is, therefore, calculated as follows:

$$
\alpha^{M}=\frac{1}{N_{F}} \sum_{i \in F}\left[\left({ }_{t} w_{i}^{F}-{ }_{0} w_{i}^{F}\right)-\sum_{j \in I} \eta_{i j}\left({ }_{t} w_{i}^{F}-{ }_{0} w_{i}^{I}\right)\right]
$$

where 0 and $t$ denote the two periods under consideration.

In this case, rather than referring to the likelihood of working in an informal job, the score indicates the probability of a formal (informal) worker in the first period moving to an informal (formal) job in the second. Probabilities are estimated using a probit function that considers the following independent variables: age, age squared, gender, education and position in the household.

The panel structure of the data partially controls for the possible impact of unobservable characteristics on earnings, but it does not control for the impact they may have on transitions between sectors.

The nearest-neighbour method is used to weight observations, i.e. the change in the level of earnings of each worker who remains in formality compared to the earnings difference of workers who move from formality to informality and have the same (or the nearest) propensity score.

We compare our results with those obtained using standard earning functions (oLs and the fixed effects model) applied to the same data from the two periods under consideration. These models include a dummy variable for informality. The fixed effects model partially controls for the impact of fixed but unobserved earning determinants. 


\section{Data}

Although Argentina does not undertake longitudinal surveys, the Permanent Husehold Survey, performed regularly by the National Institute of Statistics and Censuses (INDEC),${ }^{10}$ provides data of that type using a rotating panel sample: responding households are interviewed on four successive occasions. Consequently, by comparing the situation of an individual in those four "waves" one can deduce the changes experienced in a number of variables, including income.

The Permanent Household Survey sample consists of four rotation groups. Until 2003, surveys were carried out twice a year, in May and October, meaning that one group entered and another exited in each of the two "waves" every year. Therefore, $25 \%$ of the sample was renewed each time, so $75 \%$ of cases can be compared between two successive waves or 50\% over a 12-month period. Since the rotation scheme was altered in 2003, when the surveys began to be carried out on a quarterly basis, households are surveyed for two consecutive quarters. They are then removed for two consecutive quarters before being returned to the survey for two more quarters. Hence, $50 \%$ of the sample can be compared between the same quarters of two consecutive years. Although the surveys have been conducted since 1974, microdata for the 28 cities surveyed are only available from surveys carried out since 1996.

Two different subperiods are considered, specifically 1996-2003, when there was an upswing in the number of non-formal waged workers, and 2004-2006, when the size of the informal sector remained largely unchanged. These two periods also correspond to the aforementioned data-collection change for the permanent household survey.

For the period 1996-2003, we used data from the surveys carried out in the month of May that compares the situation of the same household or individual in two successive years, while from 2004 and 2006 we analysed data that registered changes occurring in the first six months (the first and second quarters) of two consecutive years. Consequently, changes are measured by comparing $50 \%$ of the sample in both periods. However, the proportion of households and individuals actually reinterviewed is less than that because of attrition for various reasons, such as households leaving the panel or changing address, or difficulties arising in the field work.

${ }^{10}$ For a description of the Permanent Household Survey methodology, see www.indec.gov.ar. The survey scheme was changed substantially in 2003.
As it is more beneficial to work with a large number of cases, rotation groups that entered the sample at different points were aggregated. Hence, the databases consider changes that occurred in different periods.

\section{Main results}

Table 3 sets out the earnings functions parameters calculated using the fixed effects model, to control for the impact of unobserved variables, as well as the parameters based on oLs. It can be observed that the earnings gaps between formality and informality, derived from both models, differ from zero. The formal premium is, however, less under the fixed effects model, suggesting that those effects account for some of the difference usually measured.

However, as stated previously, gaps computed from earnings functions, even those that consider fixed effects, may be biased as a result of the parametric nature of the income function estimated by oLs. Therefore, a semiparametric method that considers unobserved variables, based on panel data propensity scores, was used.

The estimated propensity scores for the three approaches considered - informal employment, informal sector employment and non-registered wage earnersshow that, in all cases, there is a negative correlation between moving from a formal to an informal job and age. Similarly, according to most of the probit models, more highly educated workers and women are less likely to enter the informal sector (see table 4). The opposite is not always true, but workers who move from informality to formality are likely to have a higher level of education. Probit models, where the size of the firm was excluded or included as an independent variable, were computed for wage earners. The model where firm size was considered shows that wage earners at larger firms have a lower (greater) chance of being non-registered (registered). The results are therefore as expected: young men and less educated workers are more likely to move from formality to informality, while wage earners employed at small firms are more likely to have precarious working conditions.

Regarding the formal sector premium, the results obtained using the panel data propensity scores approach appear to indicate that there is wage segmentation in both of the scenarios under consideration (see table 5, panel 1), i.e. the earnings of those workers who move from an informal job to a formal one increase more (or decrease less) than the earnings of those workers who remain in the informal sector. Comparing the wages of workers moving from a formal to an informal job with those who 
Argentina: earnings functions, 1996-2003 and 2004-2006

(All urban areas surveyed)

\begin{tabular}{|c|c|c|c|c|c|c|c|c|}
\hline & \multicolumn{4}{|c|}{$1996-2003$} & \multicolumn{4}{|c|}{ 2004-2006 } \\
\hline & \multicolumn{2}{|c|}{ OLS } & \multicolumn{2}{|c|}{ oLS-fixed effects } & \multicolumn{2}{|c|}{ OLS } & \multicolumn{2}{|c|}{ oLs-fixed effects } \\
\hline & $\mathrm{b}$ & Sig. & $\mathrm{b}$ & Sig. & $\mathrm{b}$ & Sig. & $\mathrm{b}$ & Sig. \\
\hline \multicolumn{9}{|l|}{ A. Informal employment } \\
\hline Head of household & 0.104 & 0.000 & & & 0.109 & 0.000 & & \\
\hline Sex & 0.182 & 0.000 & & & 0.213 & 0.000 & & \\
\hline Age & 0.051 & 0.000 & 0.000 & 0.972 & 0.043 & 0.000 & 0.026 & 0.000 \\
\hline Age squared & -0.001 & 0.000 & 0.000 & 0.115 & 0.000 & 0.000 & 0.000 & 0.000 \\
\hline Low education level & -0.478 & 0.000 & & & -0.378 & 0.000 & & \\
\hline Hours & -0.013 & 0.000 & -0.017 & 0.000 & -0.014 & 0.000 & -0.017 & 0.000 \\
\hline Public sector & 0.053 & 0.000 & 0.033 & 0.014 & 0.010 & 0.035 & 0.011 & 0.470 \\
\hline Social services & 0.021 & 0.000 & 0.038 & 0.001 & 0.027 & 0.000 & 0.033 & 0.047 \\
\hline Transportation & 0.063 & 0.000 & 0.056 & 0.001 & 0.055 & 0.000 & 0.072 & 0.001 \\
\hline Commerce & -0.084 & 0.000 & -0.071 & 0.000 & -0.107 & 0.000 & -0.020 & 0.155 \\
\hline Construction & -0.205 & 0.000 & 0.001 & 0.953 & -0.054 & 0.000 & 0.071 & 0.000 \\
\hline Industry & -0.063 & 0.000 & -0.003 & 0.805 & -0.053 & 0.000 & 0.014 & 0.369 \\
\hline Greater Buenos Aires & -0.059 & 0.000 & & & -0.210 & 0.000 & & \\
\hline Northwest Argentina & -0.471 & 0.000 & & & -0.614 & 0.000 & & \\
\hline Northeast Argentina & -0.565 & 0.000 & & & -0.672 & 0.000 & & \\
\hline Pampas & -0.309 & 0.000 & & & -0.345 & 0.000 & & \\
\hline Cuyo & -0.427 & 0.000 & & & -0.472 & 0.000 & & \\
\hline Informal employment & -0.414 & 0.000 & -0.169 & 0.000 & -0.629 & 0.000 & -0.319 & 0.000 \\
\hline Dummy-year 1 & -0.016 & 0.001 & & & 0.050 & 0.000 & & \\
\hline Dummy-year 2 & -0.010 & 0.049 & & & 0.100 & 0.000 & & \\
\hline Dummy-year 3 & -0.046 & 0.000 & & & 0.150 & 0.000 & & \\
\hline Dummy-year 4 & -0.074 & 0.000 & & & 0.202 & 0.000 & 1.405 & 0.000 \\
\hline Dummy-year 5 & -0.105 & 0.000 & & & & & & \\
\hline Dummy-year 6 & -0.340 & 0.000 & & & & & & \\
\hline Dummy-year 7 & -0.476 & 0.000 & & & & & & \\
\hline Constant & 1.608 & 0.000 & 2.204 & 0.000 & 1.338 & 0.000 & & \\
\hline $\mathrm{R}$ squared & 0.440 & & 0.156 & & 0.488 & & 0.233 & \\
\hline \multicolumn{9}{|l|}{ B. Informal sector employment } \\
\hline Head of household & 0.115 & 0.000 & & & 0.142 & 0.000 & & \\
\hline Sex & 0.088 & 0.000 & & & 0.088 & 0.000 & & \\
\hline Age & 0.056 & 0.000 & 0.000 & 0.893 & 0.058 & 0.000 & 0.029 & 0.000 \\
\hline Age squared & -0.001 & 0.000 & 0.000 & 0.091 & -0.001 & 0.000 & 0.000 & 0.000 \\
\hline Low education level & -0.474 & 0.000 & & & -0.393 & 0.000 & & \\
\hline Hours & -0.013 & 0.000 & -0.017 & 0.000 & -0.012 & 0.000 & -0.017 & 0.000 \\
\hline Public sector & 0.029 & 0.000 & 0.069 & 0.000 & 0.048 & 0.000 & 0.046 & 0.002 \\
\hline Social services & -0.074 & 0.000 & 0.062 & 0.000 & -0.067 & 0.000 & 0.054 & 0.001 \\
\hline Transportation & -0.099 & 0.000 & 0.063 & 0.000 & -0.098 & 0.000 & 0.068 & 0.002 \\
\hline Commerce & -0.166 & 0.000 & -0.056 & 0.000 & -0.195 & 0.000 & -0.010 & 0.458 \\
\hline Construction & -0.353 & 0.000 & 0.005 & 0.710 & -0.200 & 0.000 & 0.064 & 0.000 \\
\hline Industry & -0.131 & 0.000 & 0.019 & 0.144 & -0.094 & 0.000 & 0.030 & 0.067 \\
\hline Greater Buenos Aires & -0.138 & 0.000 & & & -0.275 & 0.000 & & \\
\hline Northwest Argentina & -0.488 & 0.000 & & & -0.648 & 0.000 & & \\
\hline Northeast Argentina & -0.558 & 0.000 & & & -0.683 & 0.000 & & \\
\hline Pampas & -0.360 & 0.000 & & & -0.386 & 0.000 & & \\
\hline Cuyo & -0.459 & 0.000 & & & -0.527 & 0.000 & & \\
\hline Informal sector employment & -0.262 & 0.000 & -0.044 & 0.000 & -0.370 & 0.000 & -0.081 & 0.000 \\
\hline Dummy-year 1 & -0.014 & 0.013 & & & 0.062 & 0.000 & & \\
\hline Dummy-year 2 & -0.015 & 0.007 & & & 0.122 & 0.000 & & \\
\hline Dummy-year 3 & -0.041 & 0.000 & & & 0.187 & 0.000 & & \\
\hline Dummy-year 4 & -0.064 & 0.000 & & & 0.245 & 0.000 & & \\
\hline Dummy-year 5 & -0.089 & 0.000 & & & & & & \\
\hline Dummy-year 6 & -0.281 & 0.000 & & & & & & \\
\hline Dummy-year 7 & -0.426 & 0.000 & & & & & & \\
\hline Constant & 1.543 & 0.000 & 2.104 & 0.000 & 1.020 & 0.000 & 1.172 & 0.000 \\
\hline $\mathrm{R}$ squared & 0.455 & & 0.107 & & 0.486 & & 0.089 & \\
\hline
\end{tabular}


Table 3 (concluded)

\begin{tabular}{|c|c|c|c|c|c|c|c|c|}
\hline & \multicolumn{4}{|c|}{$1996-2003$} & \multicolumn{4}{|c|}{ 2004-2006 } \\
\hline & \multicolumn{2}{|c|}{ OLS } & \multicolumn{2}{|c|}{ oLs-fixed effects } & \multicolumn{2}{|c|}{ OLS } & \multicolumn{2}{|c|}{ oLs-fixed effects } \\
\hline & $\mathrm{b}$ & Sig. & $\mathrm{b}$ & Sig. & $\mathrm{b}$ & Sig. & $\mathrm{b}$ & Sig. \\
\hline \multicolumn{9}{|l|}{ C. Wage earners } \\
\hline Head of household & 0.097 & 0.000 & & & 0.101 & 0.000 & & \\
\hline Sex & 0.097 & 0.000 & & & 0.265 & 0.000 & & \\
\hline Age & 0.043 & 0.000 & 0.000 & 0.937 & 0.048 & 0.000 & 0.027 & 0.000 \\
\hline Age squared & 0.000 & 0.000 & 0.000 & 0.136 & 0.000 & 0.000 & 0.000 & 0.000 \\
\hline Low education level & -0.451 & 0.000 & & & -0.494 & 0.000 & & \\
\hline Hours & -0.014 & 0.000 & -0.017 & 0.000 & -0.012 & 0.000 & -0.017 & 0.000 \\
\hline Public sector & -0.041 & 0.000 & 0.030 & 0.027 & 0.025 & 0.000 & 0.008 & 0.612 \\
\hline Social services & -0.077 & 0.000 & 0.048 & 0.000 & 0.109 & 0.000 & 0.049 & 0.004 \\
\hline Transportation & -0.048 & 0.000 & 0.062 & 0.000 & 0.065 & 0.000 & 0.078 & 0.000 \\
\hline Commerce & -0.156 & 0.000 & -0.056 & 0.000 & -0.081 & 0.000 & 0.000 & 0.975 \\
\hline Construction & -0.276 & 0.000 & 0.005 & 0.743 & -0.065 & 0.000 & 0.078 & 0.000 \\
\hline Industry & -0.143 & 0.000 & 0.008 & 0.553 & -0.028 & 0.000 & 0.030 & 0.063 \\
\hline Greater Buenos Aires & -0.119 & 0.000 & & & -0.241 & 0.000 & & \\
\hline Northwest Argentina & -0.448 & 0.000 & & & -0.688 & 0.000 & & \\
\hline Northeast Argentina & -0.512 & 0.000 & & & -0.727 & 0.000 & & \\
\hline Pampas & -0.337 & 0.000 & & & -0.372 & 0.000 & & \\
\hline Cuyo & -0.428 & 0.000 & & & -0.559 & 0.000 & & \\
\hline Non-registered wage earners & -0.363 & 0.000 & -0.083 & 0.000 & -0.232 & 0.000 & -0.113 & 0.000 \\
\hline Dummy-year 1 & -0.006 & 0.258 & & & 0.061 & 0.000 & & \\
\hline Dummy-year 2 & -0.002 & 0.702 & & & 0.111 & 0.000 & & \\
\hline Dummy-year 3 & -0.025 & 0.000 & & & 0.168 & 0.000 & & \\
\hline Dummy-year 4 & -0.046 & 0.000 & & & 0.225 & 0.000 & & \\
\hline Dummy-year 5 & -0.064 & 0.000 & & & & & & \\
\hline Dummy-year 6 & -0.266 & 0.000 & & & & & & \\
\hline Dummy-year 7 & -0.399 & 0.000 & & & & & & \\
\hline Size_1 & 0.112 & 0.000 & 0.085 & 0.000 & 0.254 & 0.000 & 0.087 & 0.000 \\
\hline Size_2 & 0.154 & 0.000 & 0.099 & 0.000 & 0.384 & 0.000 & 0.145 & 0.000 \\
\hline Size_3 & 0.233 & 0.000 & 0.112 & 0.000 & 0.468 & 0.000 & 0.156 & 0.000 \\
\hline Size_4 & 0.264 & 0.000 & 0.128 & 0.000 & 0.435 & 0.000 & 0.138 & 0.000 \\
\hline Constant & 1.726 & 0.000 & 2.090 & 0.000 & 0.746 & 0.000 & 1.170 & 0.000 \\
\hline $\mathrm{R}$ squared & 0.496 & & 0.132 & & 0.433 & & 0.129 & \\
\hline
\end{tabular}

Source: Prepared by the authors, on the basis of data from permanent household surveys.

Note: ols: Ordinary least squares; Sig.: Significance; b: Regression coefficient.

TABLE 4

Argentina: results of probit estimate of propensity scores, 1996-2003 and 2004-2006

(All urban areas surveyed)

\begin{tabular}{|c|c|c|c|c|}
\hline & \multicolumn{2}{|c|}{$1996-2003$} & \multicolumn{2}{|c|}{ 2004-2006 } \\
\hline & Coefficient & Sig. & Coefficient & Sig. \\
\hline \multicolumn{5}{|c|}{ From formal employment to informal employment } \\
\hline Age & -0.061 & 0.000 & -0.049 & 0.000 \\
\hline Age squared & 0.001 & 0.000 & 0.000 & 0.000 \\
\hline Sex: male & 0.246 & 0.000 & 0.183 & 0.000 \\
\hline Low education level & 0.328 & 0.000 & 0.307 & 0.000 \\
\hline Head of household & -0.058 & 0.092 & -0.052 & 0.251 \\
\hline \multicolumn{5}{|c|}{ From informal employment to formal employment } \\
\hline Age & 0.002 & 0.691 & 0.005 & 0.474 \\
\hline Age squared & 0.000 & 0.028 & 0.000 & 0.030 \\
\hline Sex: male & 0.028 & 0.341 & 0.056 & 0.102 \\
\hline Low education level & -0.436 & 0.000 & -0.491 & 0.000 \\
\hline Head of household & 0.036 & 0.248 & -0.018 & 0.618 \\
\hline
\end{tabular}


Table 4 (concluded)

\begin{tabular}{|c|c|c|c|c|}
\hline & \multicolumn{2}{|c|}{ 1996-2003 } & \multicolumn{2}{|c|}{ 2004-2006 } \\
\hline & Coefficient & Sig. & Coefficient & Sig. \\
\hline \multicolumn{5}{|c|}{ From formal sector employment to informal sector employment } \\
\hline Age & -0.047 & 0.000 & -0.057 & 0.000 \\
\hline Age squared & 0.001 & 0.000 & 0.001 & 0.000 \\
\hline Sex: male & 0.257 & 0.000 & 0.203 & 0.000 \\
\hline Low education level & 0.304 & 0.000 & -0.400 & 0.000 \\
\hline Head of household & -0.034 & 0.252 & -0.053 & 0.157 \\
\hline
\end{tabular}

From informal sector employment to formal sector employment

Age

Age squared

Sex: male

Low education level

Head of household

$\begin{array}{rrrr}0.004 & 0.508 & -0.010 & 0.171 \\ 0.000 & 0.007 & 0.000 & 0.731 \\ 0.014 & 0.672 & 0.137 & 0.000 \\ -0.382 & 0.000 & -0.372 & 0.000 \\ 0.026 & 0.420 & 0.015 & 0.699\end{array}$

From registered wage earners to non-registered wage earners

Firm size: $>500$

Firm size: $101-500$

Firm size: $26-100$

Firm size: 6-25

Age

Age squared

Sex: male

Low education level

Head of household

\section{$-0.888$}

$-0.799$

$-0.683$

$-0.412$

$-0.073$

0.001

0.242

0.182

$-0.133$

0.000
0.000
0.000
0.000
0.000
0.000
0.000
0.000
0.001

-1.155
-0.954
-0.837
-0.544
-0.063
0.001
0.156
-0.234
-0.102

0.000

0.000

0.000

0.000

0.000

0.001

0.009

0.000

0.089

From non-registered wage earners to registered wage earners

Firm size: $>500$

Firm size: 101-500

1.148

1.508

1.282

0.698

0.006

0.000

$-0.106$

Age

$-0.305$

Sex: male

0.083

$-0.102$

Low education level

Head of household

0.000

0.000

0.000

0.000

0.506

0.484

0.031

0.000

0.096

\subsection{7}

1.535

1.333

0.756

0.035

0.000

$-0.141$

0.318

$-0.073$
0.000

0.000

0.000

0.000

0.003

0.002

0.014

0.000

0.189

From registered wage earners to non-registered wage earners

(excluding firm size as an independent variable)

Age

Age squared

Sex: male

Low education level

Head of household

$-0.080$

0.001

0.046

0.398

$-0.148$

0.000
0.000
0.225
0.000
0.000

0.000

\section{$-0.066$}

0.001

0.071

0.385

$-0.111$
0.000

0.000

0.167

0.000 0.033

From non-registered wage earners to registered wage earners (excluding firm size as an independent variable)

\begin{tabular}{lrrr}
\hline Age & 0.025 & 0.001 & 0.032 \\
Age squared & 0.000 & 0.002 & 0.000 \\
Sex: male & 0.370 & 0.000 & 0.000 \\
Low education level & -0.594 & 0.000 & 0.354 \\
Head of household & 0.157 & 0.000 & -0.629 \\
\end{tabular}

Source: Prepared by the authors, on the basis of data from permanent household surveys.

Note: Sig.: Significance. 
TABLE 5

Argentina: hourly earnings differences, ${ }^{a}$ 1996-2003 and 2004-2006

(All urban areas surveyed)

\begin{tabular}{|c|c|c|c|c|c|c|c|c|c|}
\hline \multirow{2}{*}{ To } & \multirow{2}{*}{ From } & \multicolumn{4}{|c|}{$1996-2003$} & \multicolumn{4}{|c|}{ 2004-2006 } \\
\hline & & Treatment & Control & $\begin{array}{c}\text { Earning } \\
\text { difference }\end{array}$ & $t$ & Treatment & Control & $\begin{array}{c}\text { Earning } \\
\text { difference }\end{array}$ & $t$ \\
\hline & & $\mathrm{N}$ & $\mathrm{N}$ & & & $\mathrm{N}$ & $\mathrm{N}$ & & \\
\hline \multicolumn{10}{|l|}{ Panel 1} \\
\hline $\mathrm{IE}^{\mathrm{b}}$ & $\mathrm{FE}^{\mathrm{c}}$ & 1859 & 18089 & -0.139 & -8.544 & 800 & 10556 & -0.169 & -6.846 \\
\hline FE & IE & 2226 & 15632 & 0.127 & 8.408 & 1511 & 9579 & 0.193 & 10.231 \\
\hline $\mathrm{ISE}^{\mathrm{d}}$ & $\mathrm{FSE}^{\mathrm{e}}$ & 2932 & 16906 & -0.078 & -6.215 & 1361 & 11725 & -0.092 & -4.933 \\
\hline FSE & ISE & 3095 & 12091 & 0.045 & 3.162 & 1791 & 6771 & 0.107 & 5.633 \\
\hline \multicolumn{10}{|l|}{ Panel 2} \\
\hline $\operatorname{IRWE}^{\mathrm{f}}$ & FRWE $^{\mathrm{g}}$ & 1087 & 14308 & -0.008 & -0.633 & 341 & 7608 & 0.004 & 0.199 \\
\hline FRWE & IRWE & 1135 & 1829 & 0.008 & 0.404 & 443 & 649 & 0.034 & 1.147 \\
\hline INRWE $^{\text {h }}$ & FNRWE $^{\mathrm{i}}$ & 480 & 1649 & -0.061 & -1.588 & 392 & 1446 & -0.091 & -2.317 \\
\hline FNRWE & INRWE & 548 & 2567 & -0.050 & -1.488 & 429 & 1633 & -0.014 & -0.374 \\
\hline \multicolumn{10}{|l|}{ Panel 3} \\
\hline FNRWE & FRWE & 511 & 12662 & -0.066 & -2.487 & 270 & 6495 & -0.163 & -4.89 \\
\hline FRWE & FNRWE & 707 & 1685 & 0.076 & 2.622 & 579 & 1434 & 0.185 & 5.733 \\
\hline INRWE & IRWE & 213 & 1641 & -0.118 & -2.904 & 79 & 382 & -0.116 & -1.557 \\
\hline IRWE & INRWE & 258 & 2359 & 0.017 & 0.424 & 156 & 1176 & 0.083 & 1.603 \\
\hline
\end{tabular}

Panel 4

4.1 Excluding firm size as an independent variable

\begin{tabular}{|c|c|c|c|c|c|c|c|c|c|}
\hline $\mathrm{NRWE}^{\mathrm{j}}$ & $\mathrm{RWE}^{\mathrm{k}}$ & 1078 & 16462 & -0.119 & -6.246 & 481 & 8431 & -0.194 & -7.138 \\
\hline RWE & NRWE & 1347 & 4508 & 0.095 & 4.775 & 1000 & 3435 & 0.203 & 8.711 \\
\hline \multicolumn{10}{|c|}{ 4.2 Including firm size as an independent variable } \\
\hline NRWE & RWE & 1078 & 10019 & -0.109 & -5.544 & 429 & 3176 & -0.197 & -6.273 \\
\hline RWE & NRWE & 1347 & 3804 & 0.099 & 3.665 & 901 & 2172 & 0.138 & 4.061 \\
\hline \multicolumn{10}{|l|}{ Panel 5} \\
\hline INWE $^{l}$ & FRWE & 380 & 10995 & -0.184 & -4.285 & 124 & 4067 & -0.244 & -3.384 \\
\hline FRWE & INWE & 306 & 6220 & 0.212 & 4.310 & 172 & 2515 & 0.425 & 6.769 \\
\hline INWE & FNRWE & 349 & 1542 & -0.155 & -3.203 & 232 & 1231 & -0.067 & -1.06 \\
\hline FNRWE & INWE & 363 & 5639 & -0.014 & -0.296 & 283 & 2952 & -0.05 & -0.888 \\
\hline INWE & IRWE & 150 & 1442 & -0.029 & -0.550 & 47 & 221 & 0.053 & 0.555 \\
\hline IRWE & INWE & 125 & 4261 & 0.000 & 0.004 & 35 & 784 & -0.083 & -0.731 \\
\hline INWE & INRWE & 793 & 2441 & -0.004 & -0.131 & 489 & 1728 & 0.001 & 0.026 \\
\hline INRWE & INWE & 766 & 6924 & -0.117 & -3.375 & 477 & 3351 & -0.002 & -0.058 \\
\hline
\end{tabular}

Source: Prepared by the authors, on the basis of data from permanent household surveys.

Note: N: Number; $t$ : Time.

${ }^{a}$ Excluding workers in employment schemes and domestic service.

$\mathrm{b}$ IE: Informal employment.

${ }^{\mathrm{c}} \mathrm{FE}$ : Informal employment.

${ }^{d}$ ISE: Informal sector employment.

${ }^{e}$ FSE: Formal sector employment.

${ }^{\mathrm{f}}$ IRWE: Informal registered wage earner.

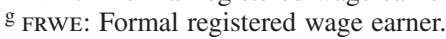

${ }^{h}$ INRWE: Informal non-registered wage earner.

${ }^{\mathrm{i}}$ FNRWE: Formal non-registered wage earner.

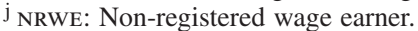

${ }^{\mathrm{k}} \mathrm{RWE}$ : Registered wage earner.

${ }^{1}$ INWE: Informal non-wage earner. 
remain in the formal sector produces symmetric results. This is true for both periods, 1996-2003 and 2004-2006, although earning gaps did increase in the second period, especially for those in informal employment.

The wage differences between formal and informal employment are larger than the differences between formal sector and informal sector employment, which suggests that employees' legal status is the main cause of such differences. This appears to be confirmed by the large differences seen when the incomes of registered and non-registered workers are compared.

In order to assess the impact of firm size and employment contract type on the earnings gap, the exercise was repeated for other, more restricted groups of workers. Since bigger firms tend to have a larger share of registered employees, the formal wage premium appears to be in fact a size wage premium. However, when the earnings comparisons are made exclusively within the group of registered wage earners or of non-registered wage earners, the earnings difference between workers in the informal and formal sectors is close to zero when we control for the employment contract type (see table 5, panel 2). A significant loss of earnings was only seen when non-registered wage earners moved from a larger firm to a smaller one during the second period. Interestingly, that loss is equivalent to approximately half of the registration premium.

When the earnings of employees with different labour contracts are compared, based on firm size, there is a significant difference from zero in most of the exercises, controlling for the difference between the formal and informal sector (see table 5, panel 3). The results are the same when an alternative method is used to control for the impact of firm size, i.e. where comparisons are made using estimated scores that include independent variables. The average income differences between registered and non-registered wage earners are similar (see table 5, panel 1 and panel 4). This supports the hypothesis that there is widespread segmentation based on workers' legal status, regardless of the size of the firm where they work.

With regard to job category, there is no difference when non-wage earners are compared to employees working in small firms, regardless of the type of labour contract (except in one comparison). Instead, registered wage earners tend to lose relative income when they become self-employed and, inversely, the earnings of non-wage earners who take up a formal position increase more than if they had remained in informality. Consequently, these exercises suggest that non-wage earners in the informal sector earn less than employees in the formal sector.

The aforementioned results, which are averages for all types of workers, could hide heterogeneity, as different groups may have different probabilities of moving and/or receive different earnings. However, estimated income gaps for different sub-groups of workers appear to show that segmentation prevails for the different identified groups, as can be seen in table 6 . Even when age, education, sex and different transition probabilities - estimated on the basis of group scoresare taken into account, there is always an income penalty. While it may not always be a significant penalty, the income of men and those with a low education level will experience greater losses (increases) when they enter (exit) informality.

\begin{tabular}{|c|c|c|c|c|}
\hline & \multicolumn{2}{|c|}{$1996-2003$} & \multicolumn{2}{|c|}{ 2004-2006 } \\
\hline & Earning difference & $t$ & Earning difference & $t$ \\
\hline \multicolumn{5}{|c|}{ Transition to informal employment } \\
\hline Scores Q 1 & -0.088 & -2.111 & -0.209 & -2.782 \\
\hline Scores Q 2 & -0.095 & -2.448 & -0.030 & -0.508 \\
\hline Scores Q 3 & -0.148 & -4.739 & -0.139 & -2.866 \\
\hline Scores Q 4 & -0.168 & -6.608 & -0.239 & -6.765 \\
\hline Female & -0.119 & -3.925 & -0.088 & -1.778 \\
\hline Male & -0.146 & -7.581 & -0.203 & -7.251 \\
\hline Low education level & -0.174 & -7.886 & -0.227 & -6.058 \\
\hline High education level & -0.092 & -3.861 & -0.123 & -3.799 \\
\hline Age $<30$ & -0.142 & -5.295 & -0.171 & -4.097 \\
\hline Age $>30$ & -0.137 & -6.709 & -0.168 & -5.515 \\
\hline
\end{tabular}


Table 6 (concluded)

\begin{tabular}{|c|c|c|c|c|}
\hline & \multicolumn{2}{|c|}{$1996-2003$} & \multicolumn{2}{|c|}{ 2004-2006 } \\
\hline & Earning difference & $t$ & Earning difference & $t$ \\
\hline \multicolumn{5}{|c|}{ Transition to formal employment } \\
\hline $\begin{array}{l}\text { Scores Q } 1 \\
\text { Scores Q 2 } \\
\text { Scores Q } 3 \\
\text { Scores Q } 4 \\
\text { Female } \\
\text { Male } \\
\text { Low education level } \\
\text { High education level } \\
\text { Age }<30 \\
\text { Age }>30 \\
\end{array}$ & $\begin{array}{l}0.048 \\
0.114 \\
0.109 \\
0.174 \\
0.112 \\
0.136 \\
0.090 \\
0.179 \\
0.132 \\
0.124 \\
\end{array}$ & $\begin{array}{l}1.375 \\
3.382 \\
3.374 \\
7.486 \\
4.617 \\
7.023 \\
4.630 \\
7.658 \\
5.640 \\
6.284 \\
\end{array}$ & $\begin{array}{l}0.132 \\
0.188 \\
0.193 \\
0.212 \\
0.143 \\
0.224 \\
0.214 \\
0.175 \\
0.260 \\
0.141 \\
\end{array}$ & $\begin{array}{l}2.942 \\
4.489 \\
4.988 \\
7.284 \\
4.949 \\
9.094 \\
8.369 \\
6.596 \\
9.208 \\
5.620 \\
\end{array}$ \\
\hline \multicolumn{5}{|c|}{ Transition to informal sector employment } \\
\hline $\begin{array}{l}\text { Scores Q } 1 \\
\text { Scores Q 2 } \\
\text { Scores Q 3 } \\
\text { Scores Q } 4 \\
\text { Female } \\
\text { Male } \\
\text { Low education level } \\
\text { High education level } \\
\text { Age }<30 \\
\text { Age }>30 \\
\end{array}$ & $\begin{array}{l}-0.068 \\
-0.043 \\
-0.087 \\
-0.096 \\
-0.077 \\
-0.079 \\
-0.098 \\
-0.052 \\
-0.083 \\
-0.076 \\
\end{array}$ & $\begin{array}{l}-2.389 \\
-1.664 \\
-3.691 \\
-4.218 \\
-3.519 \\
-5.162 \\
-5.520 \\
-3.002 \\
-3.727 \\
-4.982 \\
\end{array}$ & $\begin{array}{l}-0.038 \\
-0.061 \\
-0.075 \\
-0.131 \\
-0.036 \\
-0.112 \\
-0.107 \\
-0.077 \\
-0.111 \\
-0.082 \\
\end{array}$ & $\begin{array}{l}-0.762 \\
-1.389 \\
-2.050 \\
-4.538 \\
-0.981 \\
-5.156 \\
-3.898 \\
-3.056 \\
-3.561 \\
-3.504 \\
\end{array}$ \\
\hline \multicolumn{5}{|c|}{ Transition to formal sector employment } \\
\hline $\begin{array}{l}\text { Scores Q } 1 \\
\text { Scores Q 2 } \\
\text { Scores Q } 3 \\
\text { Scores Q } 4 \\
\text { Female } \\
\text { Male } \\
\text { Low education level } \\
\text { High education level } \\
\text { Age }<30 \\
\text { Age }>30\end{array}$ & $\begin{array}{r}-0.015 \\
0.068 \\
0.039 \\
0.058 \\
0.052 \\
0.043 \\
0.043 \\
0.045 \\
0.057 \\
0.038 \\
\end{array}$ & $\begin{array}{r}-0.432 \\
2.325 \\
1.336 \\
2.667 \\
1.891 \\
2.589 \\
2.300 \\
2.185 \\
2.298 \\
2.212 \\
\end{array}$ & $\begin{array}{l}0.077 \\
0.078 \\
0.100 \\
0.142 \\
0.074 \\
0.118 \\
0.118 \\
0.096 \\
0.147 \\
0.082 \\
\end{array}$ & $\begin{array}{l}1.513 \\
1.977 \\
2.817 \\
4.533 \\
1.952 \\
5.377 \\
4.315 \\
3.720 \\
4.689 \\
3.458 \\
\end{array}$ \\
\hline \multicolumn{5}{|c|}{ Transition to non-registered wage earners } \\
\hline $\begin{array}{l}\text { Scores Q 1 } \\
\text { Scores Q 2 } \\
\text { Scores Q 3 } \\
\text { Scores Q 4 } \\
\text { Female } \\
\text { Male } \\
\text { Low education level } \\
\text { High education level } \\
\text { Age }<30 \\
\text { Age }>30 \\
\end{array}$ & $\begin{array}{l}-0.101 \\
-0.132 \\
-0.081 \\
-0.138 \\
-0.086 \\
-0.131 \\
-0.149 \\
-0.079 \\
-0.113 \\
-0.123 \\
\end{array}$ & $\begin{array}{l}-1.789 \\
-2.874 \\
-2.161 \\
-4.941 \\
-2.673 \\
-5.645 \\
-5.635 \\
-2.946 \\
-3.976 \\
-4.835 \\
\end{array}$ & $\begin{array}{l}-0.245 \\
-0.020 \\
-0.221 \\
-0.227 \\
-0.071 \\
-0.243 \\
-0.247 \\
-0.151 \\
-0.200 \\
-0.189 \\
\end{array}$ & $\begin{array}{l}-3.373 \\
-0.287 \\
-4.068 \\
-5.827 \\
-1.436 \\
-7.577 \\
-5.983 \\
-4.220 \\
-4.607 \\
-5.451 \\
\end{array}$ \\
\hline \multicolumn{5}{|c|}{ To registered wage earners } \\
\hline $\begin{array}{l}\text { Scores Q } 1 \\
\text { Scores Q 2 } \\
\text { Scores Q } 3 \\
\text { Scores Q } 4 \\
\text { Female } \\
\text { Male } \\
\text { Low education level } \\
\text { High education level } \\
\text { Age }<30 \\
\text { Age }>30\end{array}$ & $\begin{array}{l}0.092 \\
0.044 \\
0.104 \\
0.119 \\
0.106 \\
0.089 \\
0.081 \\
0.111 \\
0.116 \\
0.072\end{array}$ & $\begin{array}{l}1.841 \\
1.044 \\
2.962 \\
3.544 \\
3.050 \\
3.787 \\
3.102 \\
3.795 \\
4.350 \\
2.460\end{array}$ & $\begin{array}{l}0.249 \\
0.140 \\
0.245 \\
0.177 \\
0.174 \\
0.208 \\
0.190 \\
0.213 \\
0.235 \\
0.156\end{array}$ & $\begin{array}{l}4.592 \\
2.782 \\
5.691 \\
4.341 \\
3.962 \\
7.602 \\
5.619 \\
6.763 \\
7.498 \\
4.525\end{array}$ \\
\hline
\end{tabular}

Source: Prepared by the authors, on the basis of permanent household surveys.

Note: $t$ : Tme; Q: Control group. 


\section{VI}

\section{Conclusions}

The existence of earnings differences between formality and informality is a relevant issue in Argentina, given the size and tenacity of the informal labour market. We explored this issue in this paper, based on two different definitions of informality: the conventional interpretation, based on the ILO perspective, and a second definition, taking into account compliance with legal and regulating aspects. According to the first definition, the informal unit typically operates in easy-entry activities and shows an unclear separation between capital and labour (informal sector employment). Informality can also be defined by the non-compliance by certain firms with labour and other regulations (informal employment). Informal employment accounted for some 55\% of urban employment in Argentina in 2005, while informal sector employment represented $38 \%$ of total employment.

The empirical evidence on segmentation, based on earnings differentials, is questionable because of the parametric methods used. To counter this, semiparametric techniques were adopted. The propensity score matching applied to the panel data means that we can compare the variation in earnings of formal workers who remain in that sector with the differences experienced by workers who moved from the formal (informal) sector to the informal (formal) sector. If there is no difference, this is a strong indication that there is no segmentation. Comparisons are made between workers with a similar propensity for sectoral transition, based on observable characteristics. Two different subperiods are considered, specifically 1996-2003, when there was an upswing in the number of non-formal wage workers, and 2004-2006, when the size of the informal sector remained largely unchanged. These two periods also correspond to the aforementioned data-collection change for the permanent household survey.

The results support the hypothesis the urban labour market in Argentina is segmented. Workers with a similar propensity to enter or exit a particular sector, based on observable characteristics, obtain different earnings. The earnings differences are greater between formal and informal employment than between formal and informal sector employment, suggesting that employees' legal status is the main reason for the differences. This is confirmed by the larger differences seen when the incomes of registered and non-registered workers are compared, which indicates that segmentation based on workers' legal status is widespread. The same trend can be seen when we compare the income gaps for different sub-groups of workers, confirming that non-wage earners in the informal sector earn less than employees in the formal sector.

\section{Bibliography}

Beccaria, L. and F. Groisman (2008), "Informalidad y pobreza en Argentina", Investigación Económica, vol. 67, No. 266, Mexico City.

De Soto, H. (1987), El otro sendero, Buenos Aires, Editorial Sudamericana.

Dickens, W. and K. Lang (1988), "The reemergence of segmented labor market theory", American Economic Review, vol. 78, No. 2, Nashville, Tennessee, American Economic Association.

Evans, D.C. and L.S. Leighton (1989), "Some empirical aspects of entrepreneurship", American Economic Review, vol. 79, No. 3, Nashville, Tennessee, American Economic Association.

Fields, G. (1990), "Labour market modelling and the urban informal sector: theory and evidence", The Informal Sector Revisited, D. Turnham, B. Salomé and A. Schwarz (comps.), Paris, Organization for Economic Cooperation and Development (OECD).

(1975), "Rural-urban migration, urban unemployment and under-development and job-search security in LCDS", Journal of Development Economics, vol. 2, No. 2, Amsterdam, Elsevier.
Harris, J.R. and M.P. Todaro (1970), "Migration, unemployment and development: a two-sector analysis", American Economic Review, vol. 60, No. 1, Nashville, Tennessee, American Economic Association.

Hart, K. (1973), "Informal income opportunities and urban employment in Ghana", The Journal of Modern African Studies, vol. 11, No. 1, Cambridge, Cambridge University Press.

Heckman, J. and V. Hotz (1986), "An investigation of labor market earnings of Panamanian males", Journal of Human Resources, vol. 21, No. 4, Wisconsin, University of Wisconsin Press.

Heckman, J. and G. Sedlacek (1985), "Heterogeneity, aggregation, and market wages functions: an empirical model of self-selection in the labor market", Journal of Political Economy, vol. 93, No. 6, Chicago, The University of Chicago Press.

Hussmanns, R. (2005), "Measuring the informal economy: from employment in the informal sector to informal employment", Working Paper, No. 53, Geneva, International Labour Organization (ILO). 
ILO (International Labour Organization) (1972), Employment, Incomes and Equality: A Strategy for Increasing Productive Employment in Kenya, Geneva.

Killingsworth, M. (1987), "Heterogeneous preferences, compensating wage differentials, and comparable worth", The Quarterly Journal of Economics, vol. 102, No. 4, Cambridge, Massachusetts, The MIT Press, November.

Lewis, A. (1954), "Economic development with unlimited supplies of labour", The Manchester School, vol. 22, No. 2, Wiley.

Magnac, T. (1991), "Segmented or competitive labour markets", Econometrica, vol. 59, No. 1.

Maloney, W.F. (1999), "Does informality imply segmentation in urban labor markets? Evidence from sectoral transitions in Mexico", World Bank Economic Review, vol. 13, No. 2, Washington, D.C., World Bank.

Packard, T. (2007), "Do workers in Chile choose informal employment? A dynamic analysis of sector choice", Policy Research Working Paper, No. 4232, Washington, D.C., World Bank.
Pagés-Serra, C. and M. Stampini (2007), "No education, no good jobs? Evidence on the relationship between education and labor market segmentation", Research Department Working Paper Series, No. 627, Washington, D.C., Inter-American Development Bank.

Perry, G. and others (2007), Informality: Exit and Exclusion in Latin America, Washington, D.C., World Bank.

Portes, A., M. Castells and L.A. Benton (1989), The Informal Economy: Studies in Advanced and Less Developed Countries, Baltimore, Johns Hopkins University Press.

Pradhan, M. and A. van Soest (1995), "Formal and informal sector employment in urban areas of Bolivia", Labour Economics, vol. 2, No. 3, Amsterdam, Elsevier.

Pratap, S. and E. Quintín (2006), "Are labour markets segmented in developing countries? A semiparametric approach", European Economic Review, vol. 50, No. 7, SAGE.

Sánchez, C., H. Palmieri and F. Ferrero (1976), "Desarrollo industrial urbano y empleo en la ciudad de Córdoba (Argentina): un caso de crecimiento desequilibrado", Geneva, International Labour Organization (ILO), unpublished. 